\title{
$\mathrm{ICl}$ CACl: Innovation meeting looking for ideas and technological solutions in favor of cardiovascular medicine
}

\author{
ICI CACl: Encuentro de innovación en busca de ideas y soluciones \\ tecnológicas a favor de la medicina cardiovascular
}

Revista Argentina de Cardioangiología Intervencionista 2020;11(1):15-16. https://doi.org/10.30567/RACI/202001/0015-0016

The ICI CACI in its first edition in South America faces the task of bringing disruptive technologies from a great variety of domains and the use of institutional resources and trained staff in order to promote medical technological solutions. In addition we will emphasize the cooperation between industry and physicians and the importance of ideas and connections.

The technological progress highlights the importance of the physician at the first line in the interface of the medical treatment and the patient, and the implementation and creation of these ideas.

The physician's environment makes possible a unique perspective of the critical points at the medical array, identifying the unmet clinical needs, the thinking process and the possibility of a wide overview of the multiple ways of a complex net as is the comprehensive medical treatment. Also poses the physician at a special position, in order to create new solutions regarding chance and improvement in the sequence of the medical services.

Dr. Rene Laennec was physician and musician and operated a successful clinic at the very beginning of the 19 th century, was quoted as saying that "his career's summit took place during a period in which medicine was not his main occupation but the right one for invent the stethoscope".

In light of the existing great variation of treatment strategies the motivation to develop better alternatives and promotion of knowledge is driven from the real need of doctors and entrepreneurs.

\section{THE ECHOSYSTEM}

The aim of ICI CACI is to put Argentina as an active and throbbing center of the entrepreneurs' echosystem in Latin America.

This powerful entrepreneurship, the human capital and fruitful activity, all together are translated in successful commercials transactions and new markets.

It is remarkable that very relevant companies dealing with medical technology and products with important clinical value, refer to doctors in order to invent, develop and update their products' portfolio.

The radiologist Julio Palmaz and the cardiologist Richard Schatz developed the stents technology. At the beginning they were financially supported by and American restaurant owner, who toll after years that his investment of $250 \mathrm{~K}$ dollars yielded about 600 million dollars at the time that Johnson and Johnson acquired all the rights of the invention.

This is an example of cooperation between inventors who are closed to the clinical activity the initial funding factor and the industry. With the FDA certification stents are implanted in more than $90 \%$ of vessels interventions.

In order to establish the priority of ICI CACI as a design partner of choice for the medical technological industry and entrepreneurs, we are going to launch the first event in Latin America at Buenos Aires, Argentina. ICI CACI pretends to be the principal pipeline for share developments in healthcare and the promotion of the benefits coming from the innovative products, to bring up disrupting technologies and the intelligent use of institutional or privates resources.

ICI CACI will use the global well known methodology AGILE, i.e. agility and easy movement.

The ICI CACI strategy is to connect with the innovation world, real partnership with entrepreneurs, startups, global companies, investors and other nations. In addition databases and acquaintance with the regulatory rules, allow ICI CACI to promote technological development in an accelerated rate providing a significant value. A varied of activity fields like pharma, medical devices, digital health, based on the creation of many domains: cyber, artificial intelligence, finance, cell therapy, biotechnology, biomaterials' engineering, etc.

ICI CACI is defined as an independent initiative and then lets this framework to move quickly and to harness us to ventures, investors funding, work spaces and entrepreneurship centers.

With this operational concept, from the point of view of the industry the way to go is done and familiar, and ICI CACI would be the mediator and accelerator between the institutional resources like university medical centers, universities and startups and the leading medical staff, research laboratories and management board. 
In our view, the most important tier is the personal relationship of the medical staff with industry's representatives composing a true "team". Doctors will be associated founders, side by side with leader entrepreneurs of the industry.

Others, may be the majority, will take the role of consultants in their specialties. The case of medical centers that are operating an innovation department, will combine forces in order to promote projects coming for the different wards or form startups.

Commercial models for cooperation with the industry would lean on transparency, agility and fairness, and most important to allow every single project to progress in the right way in order to ensure its success being the ICI CACI full partners of the success.

For the industry the closeness with ICI CACI will lead to the creation of a pilot working at the beta website. The beta website versions, is a prerelease of software that is given out to a large group of users to try under real conditions to give the possibility to create solutions that will touch the life of people all around the world, aspirating to solve complex problems in the medical contemporary field.

The biomed industry looks for the well being of patients and in parallel to be profitable: "doing well by doing good", and to build up commercial entrepreneurships to finally create a sustainable echosystem.

Alberto Hendler MD FESC PhD

Beilinson Medical Center, Cath Lab. Assuta Medical Center, Cath Lab Tel-Aviv University 